\title{
Chemical analysis of soil and leachate from experimental wetland mesocosms lined with coal combustion products
}

\author{
Changwoo Ahn and William J. Mitsch \\ Environmental Science Graduate Program, The Ohio State University
}

\begin{abstract}
Small-scale $\left(1-\mathrm{m}^{2}\right)$ wetland mesocosm experiments were conducted over two consecutive growing seasons to investigate the effects on soil and leachate chemistry of using a recycled coal combustion product as a liner. The coal combustion product used as a liner consisted of FGD (Flue-Gas-Desulfurization) by-products and fly ash. This paper provides the chemical characteristics of mesocosm soil and leachate after two years of experimentation. As, Ca, and $\mathrm{pH}$ were higher in FGD-lined mesocosm surface soil relative to unlined mesocosms. Al was higher in unlined mesocosms. No significant difference of potentially phytotoxic B was observed between lined and unlined mesocosms in the soil. Higher $\mathrm{pH}$, conductivity, and concentrations of $\mathrm{Al}, \mathrm{B}, \mathrm{Ca}, \mathrm{K}$, and $\mathrm{S}\left(\mathrm{SO}_{4}-\mathrm{S}\right)$ were observed in leachate from lined mesocosms compared to unlined controls while $\mathrm{Fe}$ and $\mathrm{Mn}$ were higher in unlined mesocosms. Concentrations of most elements analyzed in the leachate were below national primary and secondary drinking water standards after two years of experimentation. Initially high $\mathrm{pH}$ and soluble salt concentrations measured in the lined mesocosms in the leachate may indicate the reason for firstyear effects noted on the development of wetland vegetation in the mesocosms.
\end{abstract}

\section{Introduction}

Liners are important to the success of the constructed wetlands in areas where groundwater levels are typically close to the ground surface or where native soils are too permeable (Kadlec and Knight, 1996; Kadlec et al., 2000). Liners not only protect groundwater resources but also ensure that there is adequate water in the wetlands to support appropriate aquatic life, particularly wetland vegetation. The most frequently used liners for constructed wetlands are clays, clay bentonite mixtures, and synthetic materials such as polyvinylchloride (PVC) and high-density polyethylene (HDPE) (Kadlec and Knight, 1996). However, synthetic liners are potentially expensive and are prone to more damage than are clay or clay-bentonite liners (Kadlec and Knight, 1996). In addition, natural clays are not always available when and where wetlands are to be constructed.

Flue-Gas-Desulfurization (FGD) materials are produced by lime scrubbing sulfur oxides from flue gases of coal- fired electrical generating stations. Four to 6 million tons of these materials are produced annually in Ohio alone (Bigham et al., 1993). FGD materials are generally treated as waste products and landfilled. The disposal of the enormous volume of this waste generated by every power plant with sulfur scrubbers, however, has become increasingly difficult as landfill costs increase, landfill space decreases, and sulfur scrubbers are deployed in increasing numbers (American Coal Ash Association Survey, 1997). Several studies have been carried out on the reuse of FGD byproducts for land application, agricultural liming, highway and civil engineering applications, and waste-storage pond liners (Bigham et al., 1993; Stehouwer et al., 1995a, b; Stehouwer, 1996; Crews and Dick, 1998; Butalia and Wolfe, 1999), but few studies have investigated the use of this material as potential liners in constructed wetlands. The idea of using FGD by-products as liners for constructed wetlands has three possible advantages. First, the FGD material, when properly applied, can have a very low permeability (Butalia and Wolfe, 1999). Second, FGD byproducts, which are high in calcium content, can lead to increased calcium-phosphate precipitation in the wetlands, thereby enhancing the water quality function of the constructed wetlands. Third, the FGD material can be obtained in coal regions of the country at an economically attractive price.

Coal combustion products in general and FGD materials in particular need to be studied carefully to determine their potentially deleterious impacts on soil and water quality since they can leach significant amounts of soluble salts and a variety of trace elements of environmental concern (Stehouweretal., 1996; Crews and Dick, 1998). For example, one element of concern for plants grown on soils amended with FGD by-products is boron (B), since coal combustion products often contain high levels of B (Crews and Dick, 1998; Sloan et al., 1999). Although no serious phytotoxicity has been reported in previous studies (Stehouwer et al., 1995b; Stehouwer et al., 1996; Crews and Dick, 1998; Clark et al., 1999; Sloan et al., 1999), little is known about the effects of FGD by-products on rooted wetland macrophytes.

The purpose of this paper was to identify potential chemical contamination of soil and groundwater from constructed wetland systems that might use coal combustion products as liner material. In a companion study(Ahn et al., in press), the effects of using FGD material on surface water quality and vegetation production were examined from the same experiment. 


\section{Materials and Methods}

\section{Stabilized FGD By-Product}

FGD material may be dry or wet depending on the desulfurization process. The wet scrubbing process commonly used by large electric utilities in Ohio involves the injection of a reagent, typically quicklime composed of calcium carbonate $\left(\mathrm{CaCO}_{3}\right)$ and portlandite $\left(\mathrm{Ca}(\mathrm{OH})_{2}\right)$, into the flue gases. The wet product generated (referred to as FGD filter cake) is a dewatered mixture of sulfites and sulfates of the reagent, unreacted reagent, and some water. The filter cake was mixed with dry fly ash and lime $(\mathrm{CaO})$ to produce the stabilized FGD material. Stabilized FGD material used as a liner in this study was imported from the American Electric Power's Conesville Power Plant in Coshocton County, Ohio. The stabilized FGD used in this study consisted of a fly ash to filter-cake ratio $=1.25: 1$ plus $5 \%$ wt $\mathrm{CaO}$.

\section{Experimental Design}

The experiment was carried out over two growing seasons (1997 and 1998) in field conditions. A set of 20 flowthrough mesocosms $\left(1 \mathrm{~m}^{2} \times 0.6 \mathrm{~m}\right.$ polyethylene tubs; Fig. 1a) were positioned at the ORWRP (Olentangy River Wetland Research Park), a 12-ha research site located on the Columbus campus of The Ohio State University (see Mitsch et al., 1998). Stabilized FGD waste was randomly assigned to half of the mesocosms; the other half with no FGD in the tubs served as controls. Mesocosms were buried in the ground to insulate roots against freezing and received $10 \mathrm{~cm}$ of noncalcareous river pea gravel, completely covering the drain to the standpipe (Figure 1b). Ten of the 20 mesocosms were then overlain by $10-15 \mathrm{~cm}$ FGD material. Fifteen to 20 $\mathrm{cm}$ of topsoil obtained during the excavation of the mesocosm site were then added to the mesocosms as "surface soil." The FGD material was layered and compacted manually, using approximately $70-80 \mathrm{~kg}$ of weight per mesocosm. Mechanical compaction, (e.g., using a soil compactor; Goldman, 1988; Butalia and Wolfe, 1999) was not used. The FGD material was smoothed to obtain uniform, solid surface and boulders that could not be easily worked into the layer were removed. This type of light compaction allowed some portion of water in the mesocosms to seep through the FGD layer and to rise up in the standpipe connected to the bottom of the mesocosms as leachate (Figure 1b), thus represents a worst-case scenario of FGD by-product effects on water and soil.Three rhizomes of Schoenoplectus tabernaemontani (soft-stem bulrush; a.ka. Scirpus validus) were planted in each of 20 mesocosms in May 1997, two months before the first-year experiment began. This macrophyte is a common wetland plant used in constructed wetlands. Rhizomes were equally spaced lengthwise in the mesocosm, pressed just below the surface of moist soil and buried to $3 \mathrm{~cm}$ depth. Plants were well established by the beginning of the first growing season experiment as seen in Figure 1a.

A water delivery system was constructed to simulates flow-through condition of full-scale constructed wetlands for treating wastewater. This was accomplished through a series of manifolds and valves which distributed similar volumes of water from the Olentangy River to each of the twenty mesocosms. This water, moderate in nutrient concentrations $\left(\sim 0.1 \mathrm{mg}-\mathrm{P} \mathrm{L}^{-1}\right)$ was first stored in two 1600 -L tanks, then fed by gravity to each mesocosm (Figure. 1). A continuous inflow rate of $70 \mathrm{~mL} \mathrm{~min}{ }^{-1}$ was chosen as a target inflow to each mesocosm during the experiments. Steady flow rates at this scale were difficult to maintain, so a pulse system was used to deliver a similar volume of water for one hour per day to each mesocosm in the second year of study. Hydraulic loading rates (HLR) were maintained between $5-7 \mathrm{~cm}$ day $^{-1}$ in both years of the experiments with an average of $10 \mathrm{~cm}$ of mean standing water in each mesocosm.

In the second-year study, we added $\mathrm{P}$ as super phosphate $\left(\mathrm{P}_{2} \mathrm{O}_{5}, 46 \%\right)$ to 10 mesocosms (5 lined and 5 unlined) to simulate high-P loading typical of secondarily treated wastewater (2 - $\left.3 \mathrm{mg}-\mathrm{P} \mathrm{L}^{-1}\right)$. Therefore, the experimental design of the second-year study included four different treatment schemes: liner plus riverwater $(\mathrm{L}+\mathrm{R})$; no-liner plus riverwater $(\mathrm{N}+\mathrm{R})$; liner plus $\mathrm{P}$-spike water $(\mathrm{L}+\mathrm{P})$; and no-liner plus $\mathrm{P}$-spiked water $(\mathrm{N}+\mathrm{P})$.

\section{Coal Combustion Product and Soil Analysis}

Chemical analysis of the stabilized FGD material and surface soil was conducted at the Ohio Agricultural Research and Development Center (OARDC) Star lab in Wooster, Ohio. Surface soil samples were collected from approximately the top $5-10 \mathrm{~cm}$ in each mesocosm at the end of second growing season after plants were harvested. This soil layer (top $5 \mathrm{~cm}$ of the wetland sediment) is most important in a wetland in water-soil exchange processes and in nutrition for wetland plants (Johnston, 1991). Three sub-samples were taken from each mesocosm, combined into one composite sample to represent each of all 20 mesocosms, air-dried, and ground using a mortar and pestle to pass a $2-\mathrm{mm}$ screen, and extracted with the Mehlich 3 procedure (Council of Soil Testing and Plant Analysis, 1974). Elemental analyses for the soil and FGD samples were conducted by Inductively Coupled Plasma (ICP) emission spectroscopy using EPA Method PB 84 - 128677 (USEPA, 1983). B was hot-water extracted and analyzed by ICP.

\section{Leachate Analysis}

Leachate samples were obtained from standpipes (Figure 1b) connected to the bottom layer of each mesocosm. Leachate was analyzed three times per week in situ for $\mathrm{pH}$ and conductivity with a YSI data sonde. Four randomly chosen lined mesocosms and two unlined mesocosms were used for leachate collection at the end of second-year study for elements and other analysis. Leachate samples were analyzed for major and trace elements by ICP emission 
spectrometry, and for $\mathrm{Cl}^{-}, \mathrm{NO}_{3}{ }^{-}$and $\mathrm{SO}_{4}{ }^{2-}$ by ion chromatography, all by the Ohio Agricultural Research and Development Center (OARDC) Star Lab in Wooster, Ohio.

\section{Vegetation Response}

Total number of stems, number of stems bearing flowers and stem lengths were investigated weekly in each mesocosm for two growing seasons during the experiments to measure the effects of FGD material on plant growth. For the stem length, 20 randomly chosen stems were measured for each mesocosm with a ruler. Results of plant growth in the first year are reported here. Plant growth in the second year of the study, biomass production, and elemental analysis of plant tissue for this study are reported by Ahn et al. (in press).

\section{Data Analysis}

Statistical analyses for effects of treatment (FGD material) on soil and the leachate were conducted as a two-way analysis of variance using the General Linear Model (GLM) procedure in SAS (SAS, 1988) with FGD liner and P addition as main effects. Duncan's multiple tests were used to test pairwise contrasts of means for significance at $\mathrm{P}<$ 0.05 (Steel et al., 1997). In the analysis of leachate, the data were divided only by the FGD treatment because no effect of $\mathrm{P}$ addition was detected for the elements analyzed. Average of the parameters measured in both liner and noliner mesocosms were calculated and compared via twosample unpaired $t$-tests assuming unequal variance.

(a)
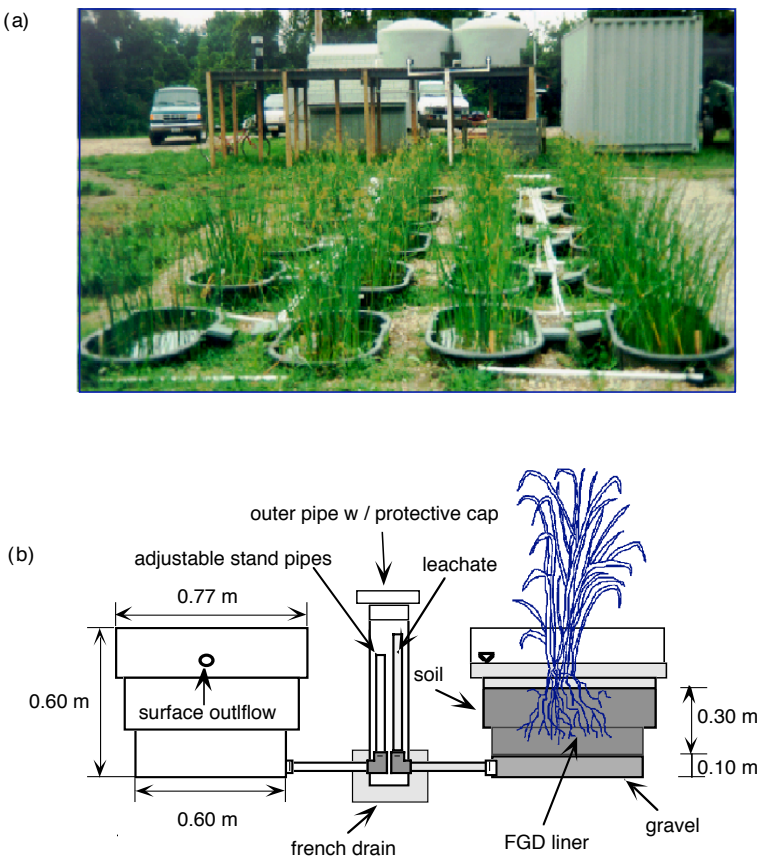

Figure 1. Experimental wetland mesocosms used in this study, showing a. layout of 20 mesocosms at the Olentangy River Wetland Research Park, Columbus, Ohio, and $b$. details of mesocosm drain system and FGD by-product placement in 10 of the 20 mesocosms.

\section{Results and Discussion}

\section{Chemical Analysis of Starting Media}

Chemical analyses of the three media used in this experiment-stabilized FGD, original topsoil, and Olentangy River water-are given in Table 1. The FGD material is quite alkaline, and has much higher concentrations than the surface soil for the following chemicals: $\mathrm{Al}, \mathrm{Ca}, \mathrm{Fe}$, $\mathrm{K}, \mathrm{Mg}, \mathrm{S}, \mathrm{As}, \mathrm{B}, \mathrm{Ba}, \mathrm{Co}, \mathrm{Cr}, \mathrm{Cu}, \mathrm{Mo}, \mathrm{Na}, \mathrm{Ni}, \mathrm{P}, \mathrm{Pb}, \mathrm{Sr}, \mathrm{V}$, and $\mathrm{Zn}$. The soil had higher concentrations of $\mathrm{Mn}$ and $\mathrm{Si}$. The Olentangy River has relatively high concentrations of $\mathrm{S}$ (as sulfate), $\mathrm{Na}$, and Clcompared to most rivers (Livingston, 1963) but otherwise was dilute in almost all metals.

\section{Soil Chemistry after the Experiment}

A variety of important biogeochemical processes in wetlands occur through the contact between standing water and the top surface soil layer. Morris and Bowen (1986), based on their sediment model calculations, showed that great changes in nutrients occur in the top $2 \mathrm{~cm}$ of the sediment layer. Furthermore, their results suggested that organic matter decompose quickly within the top $5 \mathrm{~cm}$ of sediment compared to deeper sediment in wetlands (Morris and Bowden, 1986) and, because wetland plants are generally shallow rooted, the chemistry of this surface soil will explain plant vitality. For these reasons, we wanted to see the effects, if any, of the FGD material on the surface soil in the mesocosms.

$\mathrm{pH}$ of soil was higher in mesocosms with stabilized FGD liner materials $(\mathrm{p}<0.05)$ than in mesocosms with no liners even after two growing seasons (Table 2). But the $\mathrm{pH}$ of surface soils in both FGD and control mesocosms remained circumneutral, so effects on plants and microbes in the top soil was probably minimal for this parameter. No statistical differences in conductivity of topsoil were observed in lined mesocosms compared to unlined mesocosms (Table 2). Only $\mathrm{Al}, \mathrm{As}$, and $\mathrm{Ca}$ out of twenty-two elements analyzed for the surface soil samples were found significantly different between lined and unlined mesocosms $(p<0.05)$ (Table 2). As and Ca were higher in the FGD treatment than in the controls; $\mathrm{Al}$ was lower in the FGD treatment soils than in the controls. Lower Al may be attributed to factors such as leaching and immobilization. Wendell and Ritchey (1996) also observed lower $\mathrm{Al}$ concentrations in soils amended with high-calcium FGD by-products relative to unamended controls and attributed this to both leaching and precipitation as soil Al-sulfates. Higher Ca concentrations of surface soil in lined mesocosms likely contributed to the immobilization of additional $\mathrm{P}$ as $\mathrm{Ca}-\mathrm{P}$ precipitates such as apatite $\left(\mathrm{Ca}_{5} \mathrm{Cl}\right.$, F) $\left.\left(\mathrm{PO}_{4}\right)_{3}\right)$ and hydroxylapatite $\left(\mathrm{Ca}\left(\mathrm{PO}_{4}\right)_{6}(\mathrm{OH})_{2}\right)$ (Sposito, 1989), lowering the $P$ concentrations of surface outflow. Increased phosphorus retention was observed in the lined mesocosms fed by P-spiked riverwater in the second year (Ahn et al., in press), likely a result of this greater $\mathrm{Ca}$ in the surface soil.

Boron should be closely observed in studies such as this one because fly ash, one of main components of stabilized 
Table 1. Chemical properties of the FGD by-product, topsoil, and Olentangy river water used in mesocosm wetland FGD liner study.

\begin{tabular}{|c|c|c|c|}
\hline Parameter & $\mathrm{FGD}^{\dagger}$ & Topsoil $^{\dagger}$ & Olentangy River water \\
\hline $\mathrm{pH}$ & 10.6 & 7.8 & 7.6 \\
\hline \multirow[t]{2}{*}{$\mathrm{EC}(\mu \mathrm{S} / \mathrm{cm})$} & 1000 & 510 & \\
\hline & $\left(\mathrm{g} \mathrm{kg}^{-1}\right)$ & $\left(\mathrm{g} \mathrm{kg}^{-1}\right)$ & $\left(\mathrm{mg} \mathrm{L}^{-1}\right)$ \\
\hline $\mathrm{Al}$ & 25.5 & 0.42 & 0.05 \\
\hline $\mathrm{Ca}$ & 146 & 2.4 & 62 \\
\hline $\mathrm{Fe}$ & 85 & 0.17 & 0.08 \\
\hline $\mathrm{K}$ & 2.7 & 0.06 & 3.0 \\
\hline $\mathrm{Mg}$ & 3.7 & 0.45 & 16 \\
\hline \multirow[t]{2}{*}{$S$} & 85 & 0.03 & 22 \\
\hline & $\left(\mu g^{-1}\right)$ & $\left(\mu g^{-1}\right)$ & \\
\hline As & 107 & $<0.45$ & 0.07 \\
\hline B & $356^{\ddagger}$ & 2.1 & 0.05 \\
\hline $\mathrm{Ba}$ & 140 & 40 & 0.04 \\
\hline $\mathrm{Cd}$ & $<0.2$ & 0.3 & $<0.002$ \\
\hline Co & 20 & 1.7 & $<0.01$ \\
\hline $\mathrm{Cr}$ & 51 & 0.5 & $<0.005$ \\
\hline $\mathrm{Cu}$ & 49 & 5.0 & $<0.01$ \\
\hline $\mathrm{Mn}$ & 130 & 146 & $<0.002$ \\
\hline Mo & 15 & $<0.1$ & $<0.01$ \\
\hline $\mathrm{Na}$ & 722 & 225 & 20 \\
\hline $\mathrm{Ni}$ & 48 & 3.3 & $<0.01$ \\
\hline $\mathrm{P}$ & 573 & 8.4 & 0.13 \\
\hline $\mathrm{Pb}$ & 15 & 5.0 & $<0.02$ \\
\hline $\mathrm{Si}$ & 342 & 650 & 1.8 \\
\hline $\mathrm{Sr}$ & 254 & 8.1 & 0.63 \\
\hline V & 74 & 0.6 & $<0.01$ \\
\hline $\mathrm{Zn}$ & 133 & 5.2 & 0.01 \\
\hline $\mathrm{Cl}^{-}$ & - & - & 38 \\
\hline $\mathrm{NO}_{3}^{-}$ & - & - & 2.0 \\
\hline $\mathrm{SO}_{4}^{2-}$ & - & - & 65 \\
\hline
\end{tabular}

${ }^{\dagger}$ Average of two or three randomly-taken samples.

†Total amount of B in FGD by-product; plant available B extracted out of the material by hot-water was $29.4 \mu \mathrm{g} \mathrm{g}^{-1}$.

FGD material, usually contains high B levels and can potentially cause phytotoxicity (Carlson and Adriano, 1993; Crew and Dick, 1998; Sloan et al., 1999; Clark et al., 1999). No difference was found in soil B concentrations between lined and unlined mesocosms $(\mathrm{p}<0.05)$ (Table 2).

\section{Leachate Chemistry}

$\mathrm{pH}$, conductivity, and concentrations of most elements analyzed in leachate were significantly different in lined mesocosms compared to non-lined mesocosms $(\mathrm{P}<0.05$; Table 3). $\mathrm{pH}$ of leachate was higher in lined mesocosms compared to unlined mesocosms after two growing seasons, reflecting high alkalinity produced by the liner material (probably mostly from fly ash). The $\mathrm{pH}$ of leachate increased more (up to 10) after a couple of months of the experimentation and stabilized at slightly alkaline levels (7.0 to 8.0) over time in lined mesocosms. Initially high $\mathrm{pH}$ and alkalinity can be detrimental to plant growth (see Effects on Early Vegetation Development below).
High conductivity of the leachate was observed in lined mesocosms relative to unlined mesocosms $(\mathrm{p}<0.05)$. Conductivity of leachate continued to increase in lined mesocosms over time (Ahn et al., in press), and stabilized at almost $2,000 \mathrm{mS} \mathrm{cm}^{-1}$ at the end of two growing seasons' study (Table 3). Conductivity, however, did not reach levels considered potentially detrimental to salt sensitive plants ( $4,000 \mathrm{mS} \mathrm{cm}^{-1}$ ) (Sposito, 1989).

Concentrations of $\mathrm{Al}, \mathrm{B}, \mathrm{Ca}, \mathrm{Fe}, \mathrm{K}, \mathrm{Mn}$, and $\mathrm{SO}_{4}-\mathrm{S}$ in leachate differed between lined and unlined mesocosms ( $\mathrm{p}$ $<0.05$ ). Higher concentrations of $\mathrm{Al}, \mathrm{B}, \mathrm{Ca}, \mathrm{K}$, and $\mathrm{SO}_{4}-\mathrm{S}$ were observed in leachates from lined mesocosms (Table 3 ) but the concentrations of most elements analyzed in leachates were lower than primary drinking water standards (Table 3). Calcium and $\mathrm{SO}_{4}-\mathrm{S}$ increased in the leachate by 6 and 20 times, respectively, in lined mesocosms over unlined controls; the dramatic increase is not unexpected as liner material used in this experiment consisted mainly of varying amounts of sulfates and/or sulfites of calcium $\left(\mathrm{CaSO}_{4} /\right.$ 
$\left(\mathrm{CaSO}_{4} / \mathrm{CaSO}_{3}\right.$ ) with unreacted lime and fly ash (Bigham et al., 1993). $\mathrm{SO}_{4}-\mathrm{S}$ concentrations of leachate in our study were the same as total S content. Apparently the anaerobic conditions present in the wetland mesocosms were not reduced enough to produce hydrogen sulfide. Stehouwer et al. (1996) found that more than $90 \%$ of leachate $\mathrm{S}$ was present as $\mathrm{SO}_{4}-\mathrm{S}$ from fields where FGD by-products were applied. Average leachate concentrations of $\mathrm{SO}_{4}-\mathrm{S}$ from lined mesocosms, $394 \mathrm{mg} \mathrm{L}^{-1}$, was higher than the secondary drinking water standard of $250 \mathrm{mg} \mathrm{L}^{-1}$ (Table 3). High concentrations of $\mathrm{SO}_{4}-\mathrm{S}$ in leachate from lined mesocosms after two-year experimentation suggest that this element should be carefully monitored in any large-scale application of FGD material as a liner.

Potassium was also higher in leachates from lined mesocosms compared to unlined mesocosms, clearly a result of high amounts of potassium provided by stabilized FGD materials (Table 1).

Iron and $\mathrm{Mn}$ were lower in leachates from lined mesocosm -s compared to unlined mesocosms. This may have resulted from immobilization of these elements due to increased $\mathrm{pH}$ of the soil and leachate by the alkaline FGD material used in our study. Concentrations of $\mathrm{Mn}$ were higher than secondary drinking water standards in both lined and unlined mesocosms. Of the trace elements analyzed and reported in Table $3, \mathrm{Cd}, \mathrm{Ni}$, and $\mathrm{Pb}$ were below ICP detection limits $(\mathrm{Cd}$ $<0.001 \mathrm{mg} \mathrm{L}^{-1}, \mathrm{Ni}<0.005 \mathrm{mg} \mathrm{L}^{-1}, \mathrm{~Pb}<0.02 \mathrm{mg} \mathrm{L}^{-1}$ ), suggesting no effects of the liner materials. Arsenic in some of the leachate samples from lined mesocosms was slightly higher than primary drinking water standards (Table 3).

\section{Effects on Early Vegetation Development}

Figure 2 shows vegetation morphometric measurements investigated during the first growing season of this experiment but a few months after they were planted. Significantly fewer stems, fewer stems bearing flowers, and lower stem length was observed in the lined mesocosms compared to unlined mesocosms. We believe that this effect was due to the extremely high $\mathrm{pH}$ (up to 10) observed in the leachate water soon after the experiment began.

It is also possible that early leaching of boron had a phytotoxic effect on the early wetland vegetation. Boron is known to have the greatest effects during the initial 2 - 3 years after the land application of fly ash materials (Adriano, 1980). Phytotoxic effects of B may disappear or be mitigated with time by immobilization, leaching, and plant uptake (Sposito, 1988). Ransome and Dowdy (1987) reported that B levels in soil solutions reached background levels three years after application of FGD by-products to soybean fields. Sloan et al. (1999) reported $>97 \%$ of soluble B existed as $\mathrm{H}_{3} \mathrm{BO}_{3}$, a form readily taken up by plants, in FGD by-product-treated soils. In this experiment, higher B concentrations were observed in belowground tissues of plants grown in lined mesocosms than in controls (Ahn et al., in press) although biomass production was not negatively affected. The amount of plant-available B in the FGD byproduct used in this study was low $\left(29 \mu \mathrm{g} \mathrm{g}^{-1}\right)$ (Table 1$)$ and the concentrations in the surface soil considerably lower $(\sim$ $\left.2 \mu \mathrm{g} \mathrm{g}^{-1}\right)$. Generally, B above $50-100 \mu \mathrm{g} \mathrm{g}^{-1}$ in the soil is considered high for many plants (Clark et al., 1999). Potentially phytotoxic B concentrations in leachates averaged $1.44 \mathrm{mg} \mathrm{L}^{-1}$ (Table 3). Boron in excess of $2 \mathrm{mg} \mathrm{L}^{-}$ ${ }^{1}$ in irrigation water is usually considered deleterious to certain plants (APHA, 1992); therefore it seems that B concentrations in the leachate were safe for plants, but only after the initial period of growth. Boron content of soil and water, however, should be monitored continually from the beginning of the application of the FGD materials because the difference between toxicity and deficiency for B is narrower than for most mineral elements (Sposito, 1988; Crews and Dick, 1998).

\section{Conclusions}

We believe we have identified the major limitations of FGD material to be used as liners for constructed wetlands soil contamination in the wetland and contaminated water leaching to groundwater. It appears from this study that coal combustion products such as stabilized FGD by-products may have the potential to be used as liners in constructed wetlands but only if the material is machine compacted so that leaching is minimal to nonexistent. If leaching were minimal, there would be little potential for adverse effects to groundwater. However, attention should also be paid to early release of chemicals from the liner material to overlying soils. Our study suggests that it may be desirable to delay planting a wetland for 3 - 4 months if coal combustion products are used as liners to avoid the early effects of high $\mathrm{pH}$ and possibly phytotoxic chemicals such as boron on vegetation. The susceptibility of other components of wetland ecosystem such as benthic invertebrates, especially burrowing invertebrates, and amphibians to the effects of FGD material was not investigated in this study and are currently unknown. Furthermore, long-term chronic effects of FGD material on wetland soils and water quality cannot be ascertained through this relatively short two-year study.

The relevance of our mesocosm study to field application of FGD by-products as liners in constructed wetlands may be limited because some mesocosm-scale artifacts were found during the experiments such as "pot-bound" plants after two years, and the inability to machine compact the liner material. A larger-scale, longer-term wetland experiment closer to full-scale should be conducted to better predict the effects, both positive and negative, of using FGD by-products to seal constructed wetlands before a full-scale application is attempted.

\section{Acknowledgments}

The principal sponsor of this research project is the Ohio Coal Development Office within the Ohio Department of Development (OCDO Grant CDO/D-95-10), Jackie Bird, Director. American Electric Power kindly provided the 
Table 2. Chemical properties of mesocosm wetland soils (mean \pm standard error) after two growing seasons.

\begin{tabular}{|c|c|c|c|c|}
\hline & \multicolumn{4}{|c|}{ Treatment§ } \\
\hline & $L+R$ & $\mathrm{~N}+\mathrm{R}$ & $L+P$ & $\mathrm{~N}+\mathrm{P}$ \\
\hline $\mathrm{pH}$ & $6.73 \pm 0.13 \mathrm{a} \|$ & $6.38 \pm 0.04 b$ & $6.70 \pm 0.15 a b$ & $6.57 \pm 0.10 a b$ \\
\hline \multirow[t]{2}{*}{$\mathrm{EC}(\mathrm{mS} / \mathrm{cm})$} & $862 \pm 142 a$ & $748 \pm 100 a$ & $1,080 \pm 326 a$ & $988 \pm 198 a$ \\
\hline & \multicolumn{4}{|c|}{ ( $\mu \mathrm{g} \mathrm{g}^{-1}$ soil) } \\
\hline $\mathrm{Al}$ & $484 \pm 17 b$ & $525 \pm 12 a$ & $480 \pm 28 b$ & $524 \pm 16 a$ \\
\hline As & $0.21 \ddagger \quad \mathrm{nd} \dagger$ & $0.40 \pm 0.10 a$ & $0.22 \pm 0.07 b$ & \\
\hline $\mathrm{B}$ & $1.5 \pm 0.2 a$ & $1.4 \pm 0.1 \mathrm{a}$ & $1.3 \pm 0.1 a$ & $1.3 \pm 0.1 \mathrm{a}$ \\
\hline $\mathrm{Ba}$ & $17.2 \pm 3.1 \mathrm{a}$ & $21.9 \pm 3.9 a$ & $17.0 \pm 3.8 a$ & $17.8 \pm 4.5 a$ \\
\hline $\mathrm{Ca}$ & $2858 \pm 203 a b$ & $2169 \pm 45 c$ & $3251 \pm 545 a$ & $2745 \pm 263 a b$ \\
\hline $\mathrm{Cd}$ & $0.26 \pm 0.04 a$ & $0.26 \pm 0.03 a$ & $0.23 \pm 0.05 a$ & $0.28 \pm 0.04 a$ \\
\hline Co & $1.44 \pm 0.07 a$ & $1.54 \pm 0.09 a$ & $1.45 \pm 0.13 a$ & $1.56 \pm 0.11 a$ \\
\hline $\mathrm{Cr}$ & $0.21 \pm 0.02 a$ & $0.21 \pm 0.05 a$ & $0.23 \pm 0.01 a$ & $0.25 \pm 0.04 a$ \\
\hline $\mathrm{Cu}$ & $5.4 \pm 0.7 a$ & $5.1 \pm 0.8 a$ & $5.1 \pm 0.9 a$ & $5.2 \pm 0.8 a$ \\
\hline $\mathrm{Fe}$ & $416 \pm 18 a$ & $414 \pm 31 a$ & $422 \pm 30 a$ & $421 \pm 23 a$ \\
\hline $\mathrm{K}$ & $77 \pm 8 a$ & $93 \pm 11 a$ & $78 \pm 5 a$ & $87 \pm 11 a$ \\
\hline $\mathrm{Mg}$ & $362 \pm 8 a b$ & $369 \pm 10 a$ & $342 \pm 6 b$ & $351 \pm 7 b$ \\
\hline $\mathrm{Mn}$ & $128 \pm 13 a$ & $110 \pm 8 a$ & $126 \pm 15 a$ & $102 \pm 14 a$ \\
\hline Mo & $0.06 \ddagger$ & $0.17 \pm 0.07 a$ & $0.06 \ddagger$ & $0.15 \pm 0.04 a$ \\
\hline $\mathrm{Na}$ & $74 \pm 3 a$ & $73 \pm 4 a$ & $72 \pm 4 a$ & $74 \pm 1 a$ \\
\hline $\mathrm{Ni}$ & $3.12 \pm 0.1 b$ & $3.41 \pm 0.1 a b$ & $3.41 \pm 0.1 a b$ & $3.56 \pm 0.1 a$ \\
\hline $\mathrm{P}$ & $7.1 \pm 0.3 b$ & $8.5 \pm 0.5 b$ & $9.2 \pm 1.0 a b$ & $11.5 \pm 1.3 a$ \\
\hline $\mathrm{Pb}$ & $3.85 \pm 1.3 a$ & $3.76 \pm 1.1 \mathrm{a}$ & $3.02 \pm 1.3 a$ & $3.40 \pm 1.2 a$ \\
\hline$S$ & $322 \pm 51 a$ & $221 \pm 41 a$ & $396 \pm 132 a$ & $372 \pm 88 a$ \\
\hline $\mathrm{Si}$ & $182 \pm 7 a$ & $189 \pm 4 a$ & $189 \pm 8 a$ & $192 \pm 4 a$ \\
\hline $\mathrm{Sr}$ & $23.1 \pm 1.7 a$ & $21.2 \pm 1.2 \mathrm{a}$ & $26.3 \pm 3.7 a$ & $26.0 \pm 2.3 a$ \\
\hline $\mathrm{Zn}$ & $7.74 \pm 0.88 a$ & $7.27 \pm 0.33 a$ & $6.98 \pm 0.40 a$ & $7.40 \pm 0.46 a$ \\
\hline
\end{tabular}

† nd - the concentration of the element was below the detection limit of Inductively Coupled Plasma (ICP) emission spectroscopy.

$\ddagger$ Indicates the number of samples used was one since other samples were below the detection limit.

$\S L+R=F G D$ liner + River water; $N+R=$ No-liner + Riverwater; $L+P=F G D$ liner +

Phosphorus-spiked water; $\mathrm{N}+\mathrm{P}=$ No-liner + Phosphorus-spiked water.

I Different letters in same row indicate significant difference at $P<0.05$.

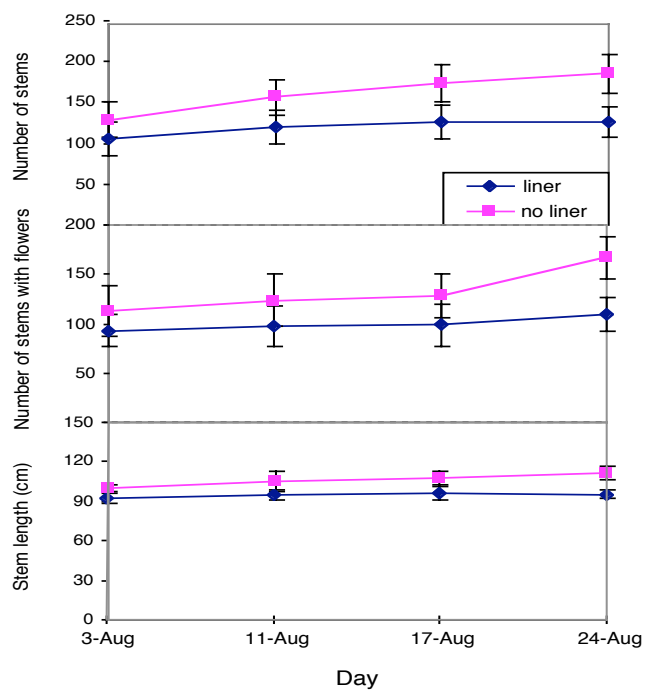

Figure 2. Morphometric measurements of plant growth in the first year of mesocosm FGD liner study including number of stems, number of stems with flowers, and average stem length.
FGD material. Some salaries were provided by the Ohio Agricultural Research and Development Center and the Environmental Science Graduate Program, both at The Ohio State University. We want to particularly thank Bill Wolfe and Tarunjit Butalia for getting us involved in these FGD studies and Bill Acton for the installation of mesocosms. We also appreciate the time of editor Warren Dick and three anonymous reviewers for a number of valuable suggestions.

\section{References}

Adriano, D. C., A. L. Page, A. A. Elseewi, A. C. Chang and I. Straughan. 1980. Utilization and disposal of fly ash and other coal residues in terrestrial ecosystems: A review. J. Environ. Qual. 9: 333 -344. 
Table 3. $\mathrm{pH}$, conductivity and elemental concentrations of leachates (mean \pm standard error) from mesocosm wetlands after two growing seasons.

\begin{tabular}{|c|c|c|c|c|c|}
\hline \multirow[t]{2}{*}{ Parameter } & & \multicolumn{2}{|c|}{ Treatment } & \multirow[t]{2}{*}{ NPDWR† } & \multirow[t]{2}{*}{ NSDWR } \\
\hline & & FGD liner & No-liner & & \\
\hline$\overline{\mathrm{pH}}$ & * & $\begin{array}{l}7.30 \pm 0.14 \\
(9.79 \pm 0.23) \Phi\end{array}$ & $\begin{array}{l}6.62 \pm 0.01 \\
(7.85 \pm 0.1) \mathbb{T}\end{array}$ & & \\
\hline $\begin{array}{l}\text { Conductivity } \\
(\mathrm{mS} / \mathrm{cm})\end{array}$ & * & $1,746 \pm 346$ & $848 \pm 86$ & & \\
\hline Al & * & $0.11 \pm 0.03$ & $0.04 \pm 0.00$ & & 0.2 \\
\hline As & & $0.06 \pm 0.02$ & $<0.035$ & 0.05 & \\
\hline B & * & $1.44 \pm 0.3$ & $0.08 \pm 0.0$ & & \\
\hline $\mathrm{Ca}$ & * & $452 \pm 124$ & $75 \pm 3$ & & \\
\hline $\mathrm{Cd}$ & & $<0.001$ & $<0.001$ & 0.005 & \\
\hline $\mathrm{Cr}$ & & $0.002 \pm 0.001$ & $<0.002$ & 0.1 & \\
\hline $\mathrm{Cu}$ & & $0.004 \S$ & $<0.002$ & 1.3 & \\
\hline $\mathrm{Fe}$ & * & $15.5 \pm 1.6$ & $22.0 \pm 2.7$ & & \\
\hline K & * & $14.4 \pm 6.4$ & $0.48 \pm 0.14$ & & \\
\hline $\mathrm{Mg}$ & & $15.6 \pm 2.2$ & $21.6 \pm 2.2$ & & \\
\hline $\mathrm{Mn}$ & * & $1.10 \pm 0.4$ & $3.52 \pm 0.1$ & & 0.05 \\
\hline $\mathrm{Na}$ & & $21.8 \pm 4.2$ & $14.9 \pm 0.3$ & & \\
\hline $\mathrm{Ni}$ & & $<0.005$ & $<0.005$ & & \\
\hline $\mathrm{Pb}$ & & $<0.02$ & $<0.02$ & 0.015 & \\
\hline $\mathrm{Zn}$ & & $0.003 \pm 0.00$ & $<0.001$ & 5.0 & \\
\hline $\mathrm{Cl}^{-}$ & & $69 \pm 1.3$ & $62 \pm 11$ & & 250 \\
\hline $\mathrm{SO}_{4}^{2-}$ & * & $394 \pm 126$ & $20.0 \pm 0.4$ & & 250 \\
\hline
\end{tabular}

\footnotetext{
* Significant difference at the 0.05 probability level between liner and unlined mesocosms. $\dagger$ National Primary Drinking Water Regulations.

‡ National Secondary Drinking Water Regulations.

(Source : USEPA, 1995).

$\S$ No standard error available because the other samples were analyzed below the detection limit of ICP. II Values in parentheses are the $\mathrm{pH}$ of leachate in the first year experiment (from Ahn et al., in press)
}

Ahn, C., W. J. Mitsch and W. E. Wolfe. In press. Effects of recycled FGD liner material on water quality and macrophytes of constructed wetlands: A mesocosm experiment. Water Research.

American Coal Ash Association Survey. 1997. 1996 Coal Combustion Product (CCP) Production and Use, American Coal Ash Association, Alexandria, VA.

APHA. 1992. Standard Methods for the Examination of Water and Wastewater. 18th Ed., American Public Health Association, American Water Works Association and Water Pollution Control Federation, Washington, DC.

Bigham, J.W., L. Foster, F. Hitzhusen, E.. McCoy, R. Stehouwer, S. Traina and W. Wolfe. 1993. Land application uses for dry FGD by-products. Phase 1 Report. The Ohio State University, Columbus. 208 pp.

Butalia, T. S. and W. E. Wolfe. 1999. Evaluation of permeability characteristics of FGD materials. Fuel 78: $149-152$.
Carlson, C. L. and D. C. Adriano. 1993. Environmental impacts of coal combustion residues. J. Environ. Qual. 22: 227 - 247.

Clark, R. B., S. K. Zeto, K. D. Ritchey and V. C. Baligar. 1999. Boron accumulation by maize in acidic soil amended with coal combustion products. Fuel 78: 179 -185 .

Council on Soil Testing and Plant Analysis, 1974. Handbook on Reference Methods for Soil Testing. Council on Soil Testing and Plant Analysis, New York.

Crews J. T. and W. A. Dick. 1998. Liming acid forest soils with flue gas desulfurization by-product: growth of Northern red oak and leachate water quality. Environ. Poll. 103: 55 -61.

Goldman L. J. 1988. Design, construction, and evaluation of clay liners for waste management facilities. EPA report, EPA/530/SW-86/007F, Office of Solid Waste and Emergency Response, United 
States Environmental Protection Agency, Washington, DC.

Johnston, C. A. 1991. Sediment and nutrient retention by freshwater wetlands: effects on surface water quality. CRC Crit. Rev. Environ. Control 21: 491-565.

Kadlec, R. H., and R. L. Knight. 1996. Treatment Wetlands. Lewis Publishers, Boca Raton, FL.

Kadlec R. H., R. L., Knight, J. Vymazal, H. Brix, P. Cooper and R. Haberl. 2000. Constructed Wetlands for Pollution Control; Processes, performances, design and operation. Scientific and Technical Report No. 8, IWA Publishing, London, England.

Livingston, D. A. 1963. Chemical Composition of Rivers and Lakes. USGS Professional Paper 440G, Washington, DC. 64 pp.

Mitsch, W. J., X.Wu, R. W. Nairn, P. E. Weihe, N. Wang, R. Deal and C. E. Boucher. 1998. Creating and restoring wetlands. BioScience 48: 1019-1030.

Morris, J. T. and W. B. Bowden. 1986. A mechanistic numerical model of sedimentation, mineralization, and decomposition for marsh sediments. Soil Sci. Am. J. 50: 96-105.

Ransome, L. S. and R. H. Dowdy. 1987. Soybean growth and boron distribution in a sandy soil amended with scrubber sludge. J. Environ. Qual. 16: 171 -175.

SAS Institute Inc. 1988. SAS/STAT User's Guide, Version 6. SAS Institute, Cary, NC.

Sloan, J. J., R. H. Dowdy, M. S. Dolan and G. W. Gehm. 1999. Plant and soil response to field-applied flue gas desulfurization residue. Fuel 78: 169 -174.

Sposito, G. 1988. Boron uptake and accumulation by higher plants: a literature review. University of California. Riverside, CA, EPRI/EA-5817.

Sposito, G. 1989. The chemistry of soils, Oxford University Press, New York.

Steel R. G. D., J. H. Torrie and D. A. Dickey. 1997. Principles and Procedures of Statistics, a Biometrical Approach, $3^{\text {rd }}$ ed. McGraw-Hill, New York, NY.

Stehouwer, R. C., P. Sutton, R. K. Fowler and W. A. Dick. 1995a. Minespoil amendment with dry flue gas desulfurization by-products: Element solubility and mobility. J. Environ. Qual. 24: 165- 174.

Stehouwer, R. C., P. Sutton and W. A. Dick. 1995b. Minespoil amendment with dry flue gas desulfurization by-products: Plant growth. J. Environ. Qual. 24: 861-869.

Stehouwer, R. C., P. Sutton and W. A. Dick. 1996. Transport and plant uptake of soil-applied dry flue gas desulfurization by-products. Soil Sci. 161: 562-574.

Wendell, R. R. and K. D. Ritchey. 1996. High-calcium flue gas desulfurization products reduce aluminum toxicity in an Appalachian soil. J. Environ. Qual. 25: $1401-1410$.

USEPA. 1983. Methods for Chemical Analysis of Water and Wastes. US Department of Commerce, National Technical Information Service, Washington, DC.

USEPA. 1995. Drinking Water Regulations and Health Advisories. EPA, Office of Water, Washington DC. 